reflecting the discussions at the Munich Pugwash Conference.)

The discussions on détente predictably led on to problems of human rights in an atmosphere largely free of acrimonious interchange of charge and countercharge. Appalling departures from acceptable standards are reported from many countries while no country seems faultless. However, the approach to human rights problems should be guided by how to help the victims. They have been used all too often for propaganda purposes or even to attempt to destabilise governments. Discussions on human rights issues tend to be simplistic, the fact that human rights cannot be separated from human responsibilities being forgotten. Nor can the question be adequately discussed in isolation from its social and political framework.

The question of energy supplies practically dominated the discussions on world resources. There was general agreement that ultimately energy needs must be met from solar, wind, geothermal and safe nuclear fusion power but no consensus about how we are to get through the next 40 or 50 years. There was some but not much enthusiasm for the fast breeder solution and a feeling that there was still some time available before committing us to a full programme of fast breeder reactor development. If a determined programme of energy saving were coupled with control of population growth, one could realistically aim for a situation in which, by the year 2020 , the world population would not rise above $6.7 \times 10^{9}$ with an average energy use of $5 \mathrm{kWt}$ (kilowatts-thermal)-8.0 $\mathrm{kWt}$ (rich nations), $3.2 \mathrm{kWt}$ (poor nations)-within a global rate of energy use of only four times that of today. It is believed such a level of demand could be met without introducing breeder technology.

\section{North-South divisions}

The problems of development loomed large in the conference discussions. Indeed, any differences in the conference were far more between North and South than between socialist and non-socialist countries. Many delegates from the Third World do indeed feel that their problems are inadequately dealt with by Pugwash and stress that problems arising from the policies of the industrialised countries relative to the Third World, the role of multinational companies, and also to a lesser extent contradictions between Third World countries themselves may represent the most serious threat to peace. On the other hand, some participants looked back somewhat nostalgically to the early Pugwash Conferences when participants were all more or less expert in some aspect of the field of nuclear weapons and it was possible to issue sharp, incisive statements in this field, carrying great weight. A few felt that there would be a case for two separate types of Pugwash Conferences, one specifically de- voted to disarmament and the other to Third World problems. This would surely be a retrograde step and could only sharpen North-South divisions and the overwhelming view was in favour of continuing as at present.

Pugwash has developed a certain mystique and influence of its own. Some may think it elitist and selfperpetuating; some may chafe at the confidentiality of the discussions, which is an essential feature of the whole Pugwash concept, but it seems that Pugwash is a powerful force for peace and understanding between nations. Thanks to a band of devoted scientists, too numerous to mention but from whom at the present time could be singled out Joseph Rotblat, Bernard Feld, Martin Kaplan, Moishe Markov and Dorothy Hodgkin, the ideas of Russell and Einstein have remained alive and the Pugwash movement has become a living movement with its members showing a genuine sense of loyalty to these ideas and of belonging to the movement.

Of the tasks ahead special emphasis should be placed on the participation of Pugwash in two vital UN meetings: the Special Session of the UN General Assembly on Disarmament in the spring of 1978, and the UN Conference on Science and Technology for Development in the summer of 1979. In both these areas the world community has grievously failed in the past. Here is perhaps an opportunity for a new beginning.

\title{
Declaration by the Pugwash Council
}

In the light of discussions at the 27th Pugwash Conference on Science and World Affairs, the Council of the Pugwash Movement feels impelled to issue the following declaration:

The world is poised for a new, more intensive and more dangerous round of the arms race. Three features of the world scene account for our sense of heightened urgency and danger:

New weapons of mass destruction. The neutron bomb is proposed for development in the heart of Europe. It is sometimes called a 'clean' or damage-free bomb. On the contrary, both its lethal radiation effects and the short and longterm biological damage it would cause are substantially greater than for existing nuclear weapons of comparable size. There would be strong induced radioactivity from neutron capture in the soil. Because of its relatively small size, it would narrow the distinction between conventional and nuclear weapons and thereby make the use of nuclear weapons more likely.

But the neutron bomb is only one example of new types of weapons now coming into military arsenals: cruise missiles, mobile ballistic missiles, and others. These are of ten provocative and thus destabilising. Their deployment is not verifiable with national means, and thus frustrate efforts at control. And the number of nuclear warheads continues to mount. The deployment of all these new weapons must be stopped.

Proliferation. There was serious concern at the conference over reports of an imminent nuclear-weapons test in South Africa. This concern was not allayed by the assurances by the South African Government that it has no intention do do so. The acquisition of nuclear weapons by South Africa would be a grave peril to the peoples of Southern Africa and the rest of the world. Developments there must be kept under intense continuing surveillance. Any collaboration with South Africa in the nuclear weapon field-whether on the governmental, commercial or scientific level-must stop. The United Nations should be urged to apply effective sanctions should South Africa be proven to be developing nuclear weapons.

But South Africa represents only the most urgent and immediate occasion for concern. At various points around the globe there have been, from time to
time, disturbing reports of states seeking nuclear weapons. We unequivocally condemn moves towards further nuclear weapon proliferation.

The failure of arms control. In spite of endless efforts. progress towards limiting armaments and stopping the arms race has been all but invisible. Everywhere there is a new sense of impasse. And this is particularly ominous in the SALT and MBFR negotiations. There is no military reason for their failure to make progress. No nation's security would be endangered, indeed it would be enhanced, by much lower levels of armaments. The obstacles are political and it requires only political will and political decisions to overcome them.

- We call on the heads of concerned governments and states all over the world, particularly of the USA and USSR, to halt new weapons deployment and reverse the arms race.

- We call on men and women everywhere to redouble their efforts to make their governments understand and act in the face of our common peril.

And we in Pugwash rededicate ourselves to the achievement of a world at peace. 